\title{
On some Plecoptera from southern Spain
}

\author{
C. Berthélemy' \\ M. Baena Ruiz ${ }^{2}$
}

Two new taxa from the Province of Córdoba, Brachyptera vera cordubensis nov. ssp. and Capnioneura gelesae nov, sp., are described and illustrated. The phyletic relationships of Letuctra andalusiaca Aubert are discussed.

Sur quelques Plécoptères du Sud de I'Espagne

Les atuteurs décrivent et figurent deux taxons nouveaux de la Province de Córdoba, Brachyptera vera cordubensis nov. ssp. et Capnioneura gelesae nov. sp., et ils discutent des relations phylétiques de Leuctra andalusiaca Aubert.

The stoneflies of the Province of Córdoba have been studied by Aubert (1963 a, b) and more recently by Puig \& Ferreras (1983). The material collected in this province by one of us (M.B.R.) includes two new taxa and an Iberian endemic species of Leuctra, $L$. andalusiaca, whose phyletic relationships are discussed below.

Brachyptera vera Berthélemy \& Gonzalez del Tánago, 1983 cordubensis nov. ssp.

Segments of the antennal flagellum longer than in $B$. vera vera (Length/width of the segments 3 to $5: 1.3-1.5$ ). As in the nominal subspecies, each segment is not parallel-sided but widens toward its apex.

Male fully winged (forewing, $9 \mathrm{~mm}$ ), not brachypterous as in $B$. v. vera. Terminal plate of the prong of the male epiproct Y-shaped (Fig. 9); this plate is $U$-shaped in $B$. v. vera (Fig. 10). In one female, the ninth sternite is distinctly longer than in any known specimen of $B$. v. vera. The two subspecies differ probably from each other in this respect but more abundant samples of both are necessary for a statistical study of this character.

1. Laboratoire d'Hydrobiologie (E.R.A. 702 du C.N.R.S.). Université Paul Sabatier, 118, route de Narbonne, 31062 Toulouse Cedex. France.

2. Gil de Alcolea 5, Baena, Córdoba, Espana.
The terminal plate of the prong of $B . v$. cordubensis shows that $B$. vera is closer to $B$. algirica Aubert (Fig. 11) than previously thought. The concavity of the posterior margin of the male ninth sternite may be a synapomorphy uniting the two species.

One male holotype and two female paratypes collected near the Rio Guadalbarbo at Espiel (UTM 30SUH258336), $640 \mathrm{~m}$ a.s.I., 25.1.1983. The Rio Guadalbarbo is a temporary stream with a moderate current in winter. Width $0.3-1.2 \mathrm{~m}$; depth $5-70 \mathrm{~cm}$; granitic pebbles and sand; Ranuncultus and Eleocharis in the stream bed: Securinega tinctoria, Rosa and Nerium oleander on the banks.

Capnioneura gelesae ${ }^{3}$ nov. sp.

Body length : male, 5-6 mm ; female, 6-7.8 mm. All specimens macropterous. Length of fore wing: male, 6.5-7.2 $\mathrm{mm}$; female, $8-9.2 \mathrm{~mm}$.

Colouration similar to that of Capnioneura libera (Navás), less contrasted than in C. mitis Despax (see Berthélemy \& Terra 1980).

Male.

The sternal areas covered with long hairs are less distinct than in C. mitis. Membranous part of the 10 th tergum large (Fig. 1). Epiproct rounded at apex, with a strong anterior subapical tooth (Figs. 2

3. Named in honour of Dr. Angeles Vazquez. 


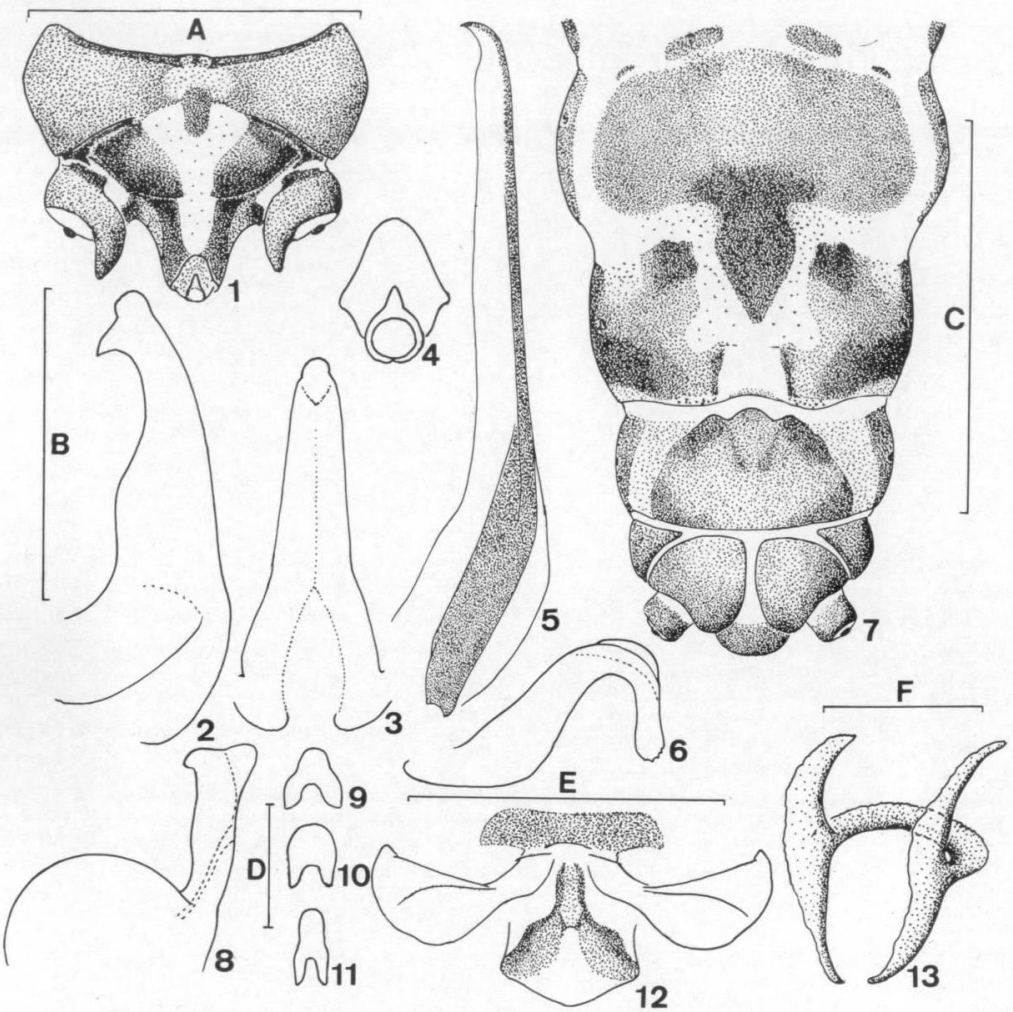

Fig. 1-7: Capnioneura gelesae nov. sp. 1, male terminalia, dorsal (scale bar A, $0.5 \mathrm{~mm}$ ) ; 2 , male epiproct, lateral (scale bar B, $0.2 \mathrm{~mm}$ ) ; id., from behind (B) ; 4, id., from above (B) ; 5, left paraproct (B) :6, specillum. left (B) : 7, female terminalia, ventral (scale bar C, $1 \mathrm{~mm}$ ). - Fig. 8-9: Brachyptera vera cordubensis nov. ssp. 8 , basal bulb and prong of the male epiproct, lateral (scale bar D, $0,2 \mathrm{~mm}$ ); 9 , terminal plate of the prong, from above (D). - Fig. 10 : id., B. vera vera (D) - Fig. 11 : id., B. algirica (D). - Fig. 12-13: Leuctra andalusiaca. 12, male last tergite and epiproct, dorsal (scale bar E, $0,5 \mathrm{~mm}$ ): 13, sclerotized ring of the spermatheca, oblique ventral view (scale bar F, $0,1 \mathrm{~mm}$ ). 
and 4). Shaft thinner than in C. libera and without the sudden narrowing seen in $C$. mitis (Fig. 3 . compare with Fig. 33 in Berthélemy \& Terra 1980 and with Fig. 31 in Berthelemy 1969). Cercal process thin, directed outwards. Specillum strongly down curved (Fig. 6). Paraprocts long, bent at the apex as in $C$. petitpierrae Aubert, outer membranous portion short (Fig. 5).

Female.

Accessory anterior sclerites generally fused to the abdominal sterna. Median extension of the 7 th sternum long, heavily pigmented, isolated from the sclerotized portions of the 8 th segment (Fig. 7). Eighth segment with two anterior dark spots and two longitudinal sclerotized and pigmented stripes. In contracted specimens, these two stripes constitute the lateral margins of a median depression. Anterior margin of the genital opening slightly sclerotized but not pigmented. Ninth sternum with a short and blunt median projection.

\section{Larva.}

The bristles of Capnioneura gelesae are distinctly longer than those of $C$. mitis. In the apical whorl of the cercal segments $5-8$ of the full-grown larva, the length of the setae is $30-35 \mu \mathrm{m}$ in $C$. gelesae and $18-23$ $\mu \mathrm{m}$ in $C$. mitis. The same differences can also be seen elsewhere, for instance on the femora.

Discussion.

The male can be separated from all other Capnioneura species by the shape of his epiproct. The pigmentation of the female is rather similar to that of C. caucasica Zhiltzova but the vulvar sclerites, well defined in that species, are absent in $C$. gelesae.

One male holotype, 9 male and 17 female paraty. pes collected near the Rio Guadalbarbo at Espiel (see above, B. v. cordubensis), 25.1.1983. 17.3.1982, 1 Q : 1.3.1983, 2 ९.

\section{Additional material.}

Rio Cuzna at Alcaracejos (30SUH294427), $560 \mathrm{~m}$. Temporary river with pools and rapids in winter. Width $3-7 \mathrm{~m}$; depth $10-160 \mathrm{~cm}$; schistous pebbles and stones; sunny river bed with Ranunculus; Nerium oleander and rushes on the banks. 25.1.1983, $3 \circ, 28$.

Rio Matapuercas at Adamuz. (30SUH640226), $460 \mathrm{~m}$. Temporary river with slow current in winter. Width $3-8 \mathrm{~m}$; depth $8-70 \mathrm{~cm}$; large stones and granitic sand ; abundant aquatic vegetation, with Ranunculus and algae: Securinega tinctoria, Nerium oleander and rushes on the banks. 25.1.1983, 5 ơ, 9 \&, 4 exuviae, 8 larvae.
Along the road from Villanueva del Duque to Adamuz, $\mathrm{km}$ 30. Sinall temporary stream at Adamuz (30SUH654187). $480 \mathrm{~m}$. Slow current in winter. Width $1 \mathrm{~m}$; depth $5-20 \mathrm{~cm}$; stones and pebbles: abundant vegetation on the banks. 25.1.1983, $2 \circ, 3 \%, 2$ exuviae.

Arroyo de la Tolva at Villaviciosa de Córdoba (30SUH 285175 ), $440 \mathrm{~m}$. Temporary stream with moderate current in winter. Width $0.7 .4 \mathrm{~m}$; depth $10.100 \mathrm{~cm}$; granitic stones and sand; Ranunculus and Oenanthe in the stream bed; Nerium oleander, Rubus and Fraxinus on the banks. 26.1.1983, 20,3 \%.

Arroyo de Don Lucas at Córdoba (30SUH39203 ), $480 \mathrm{~m}$. Small temporary stream with slow current in winter. Width $1 \mathrm{~m}$; depth $5-20 \mathrm{~cm}$; stones and pebbles; very abundant vegetation on the banks, shading the stream bed. $26.1 .1983,28$.

Capnioneuru gelesae and $C$. mitis werc collected. together in the Rio Guadalbarbo, the Arroyo de la Tolva and the Arroyo de Don Lucas. Five species of Capnioneura - half of the total number for the whole genus - have now been found in the Iberian Peninsula, including the Pyrenees.

\section{Leuctra andaluslaca Aubert, 1962.}

The shape of the male epiproct (Fig. 12) shows that $L$. andalusiaca is related not only to the Corsican $L$. fratema Morton and the Caucasian $L$. delamellata Zhiltzova but also to the hippopus sub-group ( $L$. hippopus Kempny, L. pseudohippopus Rauser, L. hippopoides Kacanski \& Zwick, $L$. gallica Aubert).

The processes of the 8 th tergite, which are united by a transverse bar in L. andalusiaca, L. fratema and $L$. delamellata, are independant in the hippopus sub-group. Since some Caucasian and Cent ral European Leuctra with united processes, such as $L$. alpina Kühtreiber, have a more primitive epiproct, the fusion of the processes represents the ancestral state and their separation the derived one. The hippopus sub-group arose from a lineage whose remnants ( $L$. andalusiaca, $L$. fratema and $L$. delamellata) have survived in Mediterranean and Caucasian refuges.

\section{Literature cited}

Aubett (J.). 1963 a - Les Plécoptères des cours d'eau temporaires de la péninsule ibérique. Mitt. schweiz. ent. Ges., 35 (1962): $301-315$

Aubert (J.). 1963 b. - Les Plécoptères de la péninsule ibérique. Eos, Rev. esp. Ent., $39:$ 23-107.

Berthélemy (C). 1969. - Les Capnioneura des Pyrénées (Plecoptera). Annls Limnol., 5 (1): 25-47.

Berthélemy (C.) \& Terra (L.S. Whyt ton da). 1980 - Plécoptères du Portugal (Insecta). Annts Limmol., 16 (2): 159-182.

Puig Garcia (M.A.) \& Ferreras Romero (M.). 1983. - Plecópteros de Sierra Morena Central (Córdoba) : datos preliminares. Actas del I congreso iberico de entomologia, León. It : 609-612. 